NATL INST. OF STAND \& TECH RIC.

\title{
Stairwell Pressurization Systems
}

Irwin A. Benjamin and John H. Klote

Center for Fire Research

National Engineering Laboratory

National Bureau of Standards

Washington, D.C. 20234

June 1979

Final Report

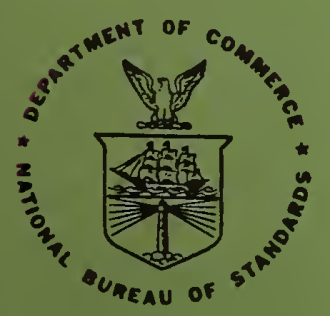

U.S. DEPARTMENT OF COMMERCE

NATIONAL BUREAU OF STANDARDS

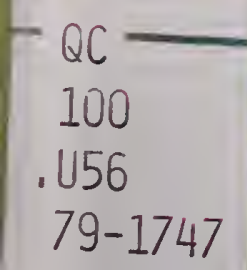



NBSIR 79-1747

\section{STAIRWELL PRESSURIZATION SYSTEMS}

Inwin A. Benjamin and John H. Klote

Center for Fire Research

National Engineering Laboratory

National Bureau of Standards

Washington, D.C. 20234

June 1979

Final Report

U.S. DEPARTMENT OF COMMERCE, Juanita M. Kreps, Secretary Jordan J. Baruch, Assistant Secretary for Science and Technology NATIONAL BUREAU OF STANDARDS, Ernest Ambler, Director 

TABLE OF C.ONTENTS

Page

LIST OF FIGURES . . . . . . . . . . . . . . . . . . . . . . iv

LIST OF TABLES . . . . . . . . . . . . . . . . . . . . iv

Abstract . . . . . . . . . . . . . . . . . . . 1

1. INTRODUCTION . . . . . . . . . . . . . . . . . . . . . . . 1

2. SINGLE INJECTION SYSTEMS . . . . . . . . . . . . . . . . . . . 2

2.1 Bottom Injection . . . . . . . . . . . . . . . 2

2.2 Top Injection . . . . . . . . . . . . . . . . 2

3. COMPARTMENTALIZATION OF STAIRWELL . . . . . . . . . . . . . . . 3

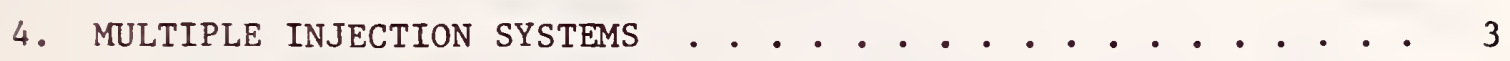

4.1. Multiple Injection with an Exhaust Fan . . . . . . . . . 3

4.2 Multiple Injection with Modulating Dampers . . . . . . . 3

4.3 Multiple Injection with an Exhaust Duct System . . . . . . 4

4.4 Multiple Injection with Barometric Dampers . . . . . . . . 4

5. FIELD TESTS • . . . . . . . . . . . . . . . . . . 5

5.1 Instrumentation . . . . . . . . . . . . . . . 5

5.2 Tracer Test Procedure . . . . . . . . . . . . . 5

5.3 Building No. 1 . . . . . . . . . . . . . . . 5

5.3.1 Pressure-Velocity Tests . . . . . . . . . 6

5.3.2 Tracer Test . . . . . . . . . . . . . 6

5.3.3 Smoke Candle Test . . . . . . . . . . 7

5.4 Building No. 2 . . . . . . . . . . . . . . . 7

5.4.1 Pressure-Velocity Tests . . . . . . . . . . 8

5.4.2 Tracer Test . . . . . . . . . . . . . . 8

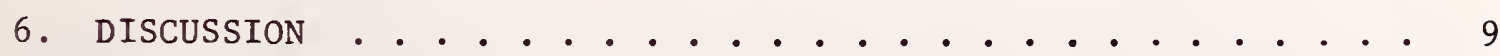

7. REFERENCES •. . . . . . . . . . . . . . . . . . 11 
Figure 1. Diagram of bottom injection stairwell pressurization system . . . . . . . . . . . . . 15

Figure 2. Diagram of top injection stairwell pressurization system..................... 16

Figure 3. Compartmentalization of stairwell in the IDS Center in Minneapolis . . . . . . . . . . . . . 17

Figure 4. Multiple injection system with an exhaust fan and a roof mounted supply fan ............ 18

Figure 5. Multiple injection system with an exhaust fan and several wall mounted supply fans... . . . . . 19

Figure 6. Typical floor plan for Building No. 1 . . . . . . 20

Figure 7. Diagram of stairwell pressurization system for Building No. 1 . . . . . . . . . . . 21

Figure 8. Second floor plan for Building No. 1 . . . . . . . 22

Figure 9. $\mathrm{SF}_{6}$ concentrations for Building No. 1 . . . . . . . 23

Figure 10. Typical floor plan for Building No. 2 . . . . . . . . 24

Figure 11. Dlagram of stairwell pressurization system for Building No. 2 . . . . . . . . . . . . 25

Figure 12. Second floor plan for Building No. 2 . . . . . . . 26

Figure 13. $\mathrm{SF}_{6}$ concentrations for Building No. 2 . . . . . • . 27

\section{LIST OF TABLES}

Page

Table 1. Differential pressures across stairwell doors and average supply and exhaust velocities for Building No. 1. . . . . . . . . . . . 13

Table 2. Differential pressures across stairwell doors and average velocities at supply grills for Building No. 2 . 
Irwin A. Benjamin and John H. Klote

\section{Abstract}

The use of stairwell pressurization systems has grown in the U.S. over the past few years. However, there are no accepted design procedures for the systems. The paper discusses several of the designs now being used in the U.S., with some of the assumptions used for design of the systems. In particular, single and multiple injection systems are discussed. A report is made on field tests on two systems. The testing is part of a continuous program to evaluate alternate systems, in an attempt to establish design recommendations for the future.

Key words: Bottom injection; multiple injection; smoke candle test; smoke control; stairwell pressurization; top injection; tracer gas test.

\section{INTRODUCTION}

Smoke is recognized as a major killer in fire situations. Smoke movements in high-rise buildings are primarily caused by the bouyancy forces of hot gases and by stack effect due to indoor and outdoor temperature differences. These forces usually cause smoke to travel up stairwells, elevator shafts, mechanical shafts and even mail chutes. This vertical movement through these shafts speeds up smoke infiltration of the upper floors. In addition, the smoke logged stairwells and elevator shafts block evacuation and obstruct fire fighting. Benjamin, Fung and Roth [1] ${ }^{1}$ provide the principle of smoke movements in buildings.

In an effort to provide smoke-free stair passages during the fire, a number of stalrwells have been built with pressurization systems. Ideally these systems use air pressure to prevent smoke infiltration. $\wedge$ number of papers and articles have been written concerning the analysis and design of pressurized stairwells [2-5]. Tamura and Shaw [6] generaterl detailed data on air flow in stair shafts.

Pressurized stairwell systems maintain design pressures when all the stairwell doors are closed. These pressures may result in unreasonably high door opening forces. However, when only one door is opened the pressure drops dramatically. In some cases the opening of only a few doors can cause system failure since the drop in stairwell pressure will allow reverse air flows from the building into the stairwell.

\footnotetext{
${ }^{1}$ Numbers in brackets refer to the 1 iterature references 1 isted at the end of this paper.
} 
With the increase in building $\operatorname{code}^{2}$ requirements for pressurized stairwells and the lack of any explicit design criteria there has arisen a multiplicity of design practices in the U.S.A. Many designers have approached the problem with novel solutions, using a variety of design assumptions. In view of the diversity of approaches, NBS has undertaken a study to catalog the many ideas being used and make this knowledge more widely available. The current program has a twofold purpose:

1. To list the many pressurization schemes being used.

2. To evaluate by field tests the efficacy of some of the schemes.

This paper is a preliminary report oriented to this goal and contains a report of the field tests on two different pressurized stairwe11s.

\section{SINGLE INJECTION SYSTEMS}

The single injection system uses only one blower to introduce pressurized air into the stairwell.

\subsection{Bottom Injection}

The bottom injection system has pressurization air supplied at the stairwell bottom and may have an exhaust vent or fan located at the top. Figure 1 is a diagram of a bottom injection system. The Polytechnic Institute of Brooklyn has performed extensive tests on a 22 story bottom injection system [10]. This system had an injection rate of $14000 \mathrm{l} / \mathrm{s}$ $(30,000 \mathrm{cfm})$ and an exhaust rate of $3800 \mathrm{l} / \mathrm{s}(8,000 \mathrm{cfm})$. With all the doors closed the differential pressure across the first floor door was 260 pascals $\left(1.05\right.$ inches $\left.\mathrm{H}_{2} 0\right)$. Under these conditions the first floor door would require approximately 310 newtons (70 pounds) opening force. When the doors on the $6 \mathrm{th}, 7 \mathrm{th}$ and $8 \mathrm{th}$ floors were all open, the system failed to maintain positive pressures within the stairwell above the tenth floor. The reason for this failure was that the stairwell exhaust fan pulled air from the upper floors into the stairwell. The New York City Local Law 5 required stairwell pressurization by such a bottom injection system with a roof mounted exhaust. Because these systems are unworkable for tall buildings, the New York Supreme Court rendered this law void in January 1977.

\subsection{Top Injection}

The top injection system has pressurization air supplied at the top and may have an exhaust vent or fan located at the bottom. Figure 2 is a diagram of such a system. Tests on a 12 story top injection system were performed by Fung [11]. In this system, the ground level door has

2 Pressurized stairwells are required by the Standard Building Code [7], the Basic Building Code [8], the Uniform Building Code [9], and many local building codes. 
an automatic opening device connected to the building fire alarm system. The injection fan supplies air at $5400 \mathrm{l} / \mathrm{s}(11,500 \mathrm{cfm})$ and all the doors are weather-stripped to reduce losses. The system was tested with nnly the ground floor door open and then with the eleventh floor and the ground floor doors open. Under these conditions the system maintained sufficient pressure differentials. However, no tests were made with more doors open as would likely be the case during a real fire situation. In addition, the success of this system depends upon weather-stripping, which may be subject to damage during the life of a building. Nonetheless, the study did show that top injection systems can be successful for short stairwells.

\section{COMPARTMENTALIZATION OF STAIRWELL}

In order to maintain differential pressures in tall stairwells, the stairwell can be divided into compartments. This was done with a 50 story stairwell at the Investor's Diversified Services (IDS) Center in Minneapolis [12]. Figure 3 is a diagram of this system. The stairwell is divided into three 14 story compartments and one 8 story compartment. Each compartment is separated from the others by partitions with doors. Approximately $3800 \mathrm{l} / \mathrm{s}(8,000 \mathrm{cfm})$ of air is supplied to each compartment from the normal building supply air systems. In order to maintain a maximum pressure of 37 pascals $\left(0.15\right.$ inch $\left.\mathrm{H}_{2} \mathrm{O}\right)$ the position of the supply dampers is controlled by a static pressure sensor located within the stairwell. This stairwell has been tested by Integrated Systems Inc., however, the test results are not yet available.

\section{MULTIPLE INJECTION SYSTEMS}

Another approach to maintaining pressure in tall stairwells is multiple injection. In general, these systems have an air supply at a number of floors over the height of the stairwell. Following is a description of some of the different multiple injection systems.

\subsection{Multiple Injection with an Exhaust Fan}

Two different variations of this system have been observed in existing buildings in Nashville, Tennessee. One has a roof mounted supply fan as shown in figure 4. The other has individual wall mounted supply fans as shown in figure 5. The wall mounted fans represent a considerable cost saving as opposed to the roof system which required construction of a separate duct chase. Later in this report there is a discussion of field tests on two stairwells with roof mounted fans. There are also plans to field test the system with the wall mounted fans in the near future.

\subsection{Multiple Injection with Modulating Dampers}

In this system the stairwell pressure is maintained by controlling the position of the supply dampers by a static pressure sensor which 
senses the differential pressure between the stairwell and the building. This is essentially the same control method used in the IDS Center stairwe11. A multiple injection system with this control system was installed in a 36 story building owned by the Commercial Union Assurance Companies, Boston [13]. This system has 14 supply air points and 13 static pressure sensors located at various heights in the stairwell. The system is supplied from two fans located on the 12 th and 36 th floors. The system was designed to maintain differential pressures in the range of 1.25 pascals $\left(0.005\right.$ inches $\mathrm{H}_{2}$ ) to 100 pascals $\left(0.4\right.$ inches $\left.\mathrm{H}_{2} \mathrm{O}\right)$ with total air injection of $33,700 \mathrm{l} / \mathrm{s}(71,500 \mathrm{cfm})$. This system was tested by the design engineers. With all doors closed the differential pressures ranged from 95 pascals $\left(0.38\right.$ inches $\left.\mathrm{H}_{2} \mathrm{O}\right)$ to 5 pascals $\left(0.02\right.$ inches $\mathrm{H}_{2} 0$ ). With five doors open the differential pressures ranged from 20 pascals ( 0.08 inches $\mathrm{H}_{2} 0$ ) to 2.5 pascals $\left(0.01\right.$ inches $\mathrm{H}_{2} 0$ ). The pressure of 2.5 pascals is sufficient to prevent infiltration of cold smoke.

\subsection{Multiple Injection with an Exhaust Duct System}

This system uses the natural resistance of a ducted exhaust system to control differential pressures. When all the stairwell doors are closed air is relieved through the exhaust duct system preventing excessive pressure buildup and thus preventing excessive door opening forces. However, when one or more doors are open the stairwell pressure drops and flow through the exhaust duct will correspondingly decrease. Ideally this allows sufficient stairwell pressures to prevent smoke infiltration when several doors are open. This system eliminates the static pressure sensors and modulating supply dampers of the previous system and therefore most likely increases reliability. Such a system was designed for a 31 story office building in San Francisco. The system was designed with supply rate of $280 \mathrm{l} / \mathrm{s}(600 \mathrm{cfm})$ per floor or $8780 \mathrm{l} / \mathrm{s}(18,600 \mathrm{cfm})$ total supply air. The system was balanced by adjusting the free area of the supply and return grills. Pressure tests of this system have not yet been performed.

\subsection{Multiple Injection with Barometric Dampers}

This system operates in a similar manner to the previous one except that the pressure is regulated by a barometric damper rather than the exhaust duct system. When all the doors are closed the barometric damper is open preventing excessive stairwell pressures. However, when a door opens, the stairwell pressure drops causing the barometric damper to close. This should allow sufficient stairwell pressure to prevent smoke infiltration. This system eliminates the need for an expensive exhaust duct system. This type of system has also been designed for the 16 story Affiliated Hospital Center in Boston. As in the previous system this was designed with a supply rate of $280 \mathrm{l} / \mathrm{s}(600 \mathrm{cfm})$ per floor. Pressure tests of this system have not yet been performed. 


\section{FIELD TESTS}

Field tests were performed on two stairwells with multiple injection systems in different buildings in Nashville. Tennessee using sulfur hexafluoride $\left(\mathrm{SF}_{6}\right)$ as a tracer. Both stairwells have roof mounted exhaust fans, as required by the Standard Building Code [7].

\subsection{Instrumentation}

Velocity measurements were performed using a thermo-anemometer. Static pressure differences were measured by a Magnahelic pressure gauge. $\mathrm{SF}_{6}$ samples were analyzed by a portable gas chromatograph having an electron capture cell fitted with a $300 \mathrm{mc}$ tritium source.

\subsection{Tracer Test Procedure}

The tracer gas, $\mathrm{SF}_{6}$, was released at a relatively constant rate from a simulated burn room. Samples throughout the building were taken and analyzed to determine smoke movement in the event of a real fire. The burn room doorway was covered with a cardboard mask in which a fan was located. The fan produced a constant flow of air mixed with $\mathrm{SF}_{6}$ from the burn room into the corridor. The $\mathrm{SF}_{6}$ flow was produced by a slight turn of a needle valve producing burn room concentrations of 550 $\mathrm{ppb}$ for the test on Building No. 1 and $350 \mathrm{ppb}$ for the test on Building No. 2. Data reduction of samples less than $200 \mathrm{ppb}$ was by means of interpolation between several data points. These data points were obtained by different dilutions of a standard $\mathrm{SF}_{6}$ sample of concentration $200 \mathrm{ppb}$. Data reduction of higher concentration samples was by means of an empirical relationship developed by Hunt and Treado [14]. In future tests lower burn room concentrations will be attempted to eliminate the use of the empirical formula and to allow operation in the more sensitive region of the gas chromatograph.

\subsection{Bullding No. 1}

Building No. 1 is an eight story apartment building for the aged. Figure 6 is a typical floor plan. When these tests were performed, construction of the building had just finished but the building was unoccupied. Consequently, the building was initially unheated. However, the building manager was able to supply heat for the SF6 test. Both stairwells have the same pressurization system design therefore tests were performed primarily on Stairwell No. 2. Figure 7 is a diagram of this pressurization system. The system has a roof mounted exhaust fan and a roof mounted supply fan which supplies pressurization air through a masonry shaft $0.46 \mathrm{~m}$ by $1.07 \mathrm{~m}$ ( $1.5 \mathrm{ft}$ by $3.5 \mathrm{ft}$ ). The supply shaft is located next to the stairwell and there is an injection point at each floor. The supply fan had a rated capacity of $3800 \mathrm{l} / \mathrm{s}$ $(8,000 \mathrm{cfm})$ at 156 pascals $\left(0.625\right.$ inches $\left.\mathrm{H}_{2} 0\right)$. The exhaust fan had a rated capacity of $1180 \mathrm{l} / \mathrm{s}(2,500 \mathrm{cfm})$ at 31 pascals $\left(0.125\right.$ inches $\mathrm{H}_{2}(\mathrm{O})$. 


\subsubsection{Pressure-Velocity Tests}

Supply and exhaust velocities and differential pressures across stairwell doors were measured with the pressurization system operating. The results of these tests with all doors closed and with some doors open are 1isted in table 1. Velocity measurements were taken approximately $0.05 \mathrm{~m}$ (2 inches) in front of the supply and exhaust grills. Average velocities were obtained by making a transverse of six points. Because the velocity measurements were taken in front of the grills, they cannot be used to determine accurate volumetric flow rates. However, some useful observations can be made from the velocity data. The supply system was very unbalanced with velocities varying from 0.3 to $2.9 \mathrm{~m} / \mathrm{sec}$ ( 60 to $570 \mathrm{ft} / \mathrm{min}$ ) with all the stairwell doors closed. Furthermore, when doors are open all the velocities increase with the largest increases at the floors where the doors are open. This is probably due to increased fan flow rate when it is operating at a lower static pressure. When two doors are opened the exhaust velocity decreases as might be expected. However, when three doors were open the velocity increased, which was unexpected. This may have been caused by the fan controls which were designed to maintain relatively constant flow.

With all the doors closed the system maintained pressures in the range of 60 to 67 pascals $\left(0.24\right.$ to 0.27 inches $\left.\mathrm{H}_{2} 0\right)$. Then two doors were open this pressure dropped dramatically. The pressures generally dropped more when additional doors were opened. The exception to this was the differential pressure across the roof door. However, the pressure differential was with respect to the outside and was therefore greatly affected by the wind. In addition, the roof door was tightly weather-stripped and had to be cracked open for the differential pressure measurement. This caused an error for the roof door pressures on the low side by as much as 7.5 pascals $\left(0.03\right.$ inches $\left.\mathrm{H}_{2} 0\right)$.

\subsubsection{Tracer Test}

For the tracer test the building was heated to $21^{\circ} \mathrm{C}\left(70^{\circ} \mathrm{F}\right)$. The simulated burn room was located on the second floor as shown in figure 8. The elevator lobby doors were closed on all floors except for the doors on the second floor on the side of the lobby leading toward the burn room. Under normal conditions this door would have been closed, however, it was left open under the belief that this would be a more severe test of the stairwell pressurization system. Figure 9 shows the $\mathrm{SF}_{6}$ concentrations during this test. On the second floor, the $\mathrm{SF}_{6}$ concentration is much lower at the corridor outside of Stairwel] No. 2 than at the elevator lobby, indicating that the air flow direction is from the stairwell to the elevator lobby. At 15 minutes the stairwcll concentrations were below $2 \%$ of the burn room concentration. The concentration remained below $2 \%$ at the second floor of the stairwell but it rose to $7.5 \%$ on the eighth floor. This concentration is quite high considering that all the stairwell doors were closed and stairwell differential pressures were at the maximum. 
At approximately 33 minutes into the test a sample was taken directly from the supply grill in the stairwell on the first floor. The concentration was $6.2 \%$ of the burn room. Next a sample was taken at the inlet to the supply fan on the roof. This was $3.3 \%$ of the burn room. The wind was 1.8 to $5.1 \mathrm{~m} / \mathrm{sec}$ (350 to $1000 \mathrm{ft} / \mathrm{min}$ ) southwest and appears to have carried the $\mathrm{SF}_{6}$ from the roof vents into the supply fan inlet. Air samples were taken at a number of locations on the roof and the $\mathrm{SF}_{6}$ concentration ranged from 4.5 to $100 \%$ of the burn room. The highest concentrations were near the elevator vent which was located approximately $30 \mathrm{~m}$ (100 ft) from the inlet to the stairwell pressurization fan. A spot check of Stairwell No. 1, at the opposite end of the building, gave an $\mathrm{SF}_{6}$ concentration less than one percent of burn room.

\subsubsection{Smoke Candle Test}

A smoke candle test was performed to visually determine the exact path of $\mathrm{SF}_{6}$ tracer into Stairwell No. 2. Two smoke candles (3-minute duration) were simultaneously ignited in the second floor corridor in front of the burn room of the $\mathrm{SF}_{6}$ test. The $\mathrm{fan}_{\text {in }}$ the burn room doorway was operating in order to reproduce the conditions of the earlier test. As in the earlier test the fire doors to the elevator lobby were closed on all floors with the exception of the doors on the second floor lobby toward the burn room.

Upon ignition of the candle the corridor filled rapidly with smoke. Three apartments on the fire corridor were occupied by members of the Nashville Fire Marshal's office. Smoke leaked into these apartments through cracks around the closed doors forcing the occupants to windows and balconies. After the corridor had filled with smoke, the door to Stairwell No. 2 was opened. The air flow from the pressurized stairwell forced the smoke down the corridor to within $1.5 \mathrm{~m}(5 \mathrm{ft}$ ) of the smoke candles. This resulted in a section of corridor $6 \mathrm{~m}(20 \mathrm{ft})$ long, between the room and the stairwell, which was relatively free of smoke. A small quantity of smoke emerged on the roof from a toilet exhaust fan which was not operating because the building was unoccupied. This was shortly followed by a large quantity of smoke flowing from the elevator vents. This flow lasted about 20 minutes and was carried by the wind in the direction of the pressurization fan for Stairwell No. 2. However, the smoke was considerably diluted when it reached the fan intake. Throughout the smoke candle test, smoke was not visible in the stairwell and only the faintest smoke odor could be detected in the stairwell.

\subsection{Building No. 2}

Building No. 2 is nominally a 16 story apartment building for the aged. Figure 10 is a typical floor plan. The floor numbering system used for this building eliminated the thirteenth floor so that the fourteenth floor is directly above the twelfth floor. At the time of these tests the building construction was not finished. During the test interior construction was underway in the north and south wings. Construction was finished on the east wing which was partially occupied. 
Tests were therefore limited to Stairwell No. 3. Figure 11 is a diagram of this pressurization system. During normal operation this system supplies conditioned ventilation air to the corridors. There are corridor supply grills on each floor but there are only six stairwell supply grills. The stairwell supply grills are located at the landings just above the $2 \mathrm{nd}, 3 \mathrm{rd}, 6 \mathrm{th}, 9 \mathrm{th}, 12 \mathrm{th}$ and $17 \mathrm{th}$ floors. In a fire situation dampers leading to the corridor supply grills close and dampers to the stairwell supply grills open. Pressurization air is supplied by a roof nounted alr handling unit which contains heating and cooling coils and a fan of rated capacity of $5000 \mathrm{l} / \mathrm{s}(10,500 \mathrm{cfm})$ at 250 pascals $\left(1.0\right.$ inch $\left.\mathrm{H}_{2} \mathrm{O}\right)$. The roof mounted exhaust $f$ an was rated at $1180 \mathrm{l} / \mathrm{s}(2,500 \mathrm{cfm})$ at 31.3 pascals $\left(0.125\right.$ inches $\left.\mathrm{H}_{2} 0\right)$.

A static pressure sensor located in the sixth floor of the mechanical shaft was designed to control the exhaust fan. When the pressure difference between the stairwell and the mechanical shaft reaches 75 pascals ( 0.3 inches $\mathrm{H}_{2} \mathrm{O}$ ) the exhaust $\mathrm{fan}$ dampers are opened and the exhaust fan is turned on. However, in these tests the pressure differential never reached 75 pascals and accordingly the exhaust fan was never actuated.

\subsubsection{Pressure-Velocity Tests}

Supply velocities and differential pressures across stairwell doors were measured with the pressurization system operating. The results of these tests with all doors closed and with some doors open are listed in table 2. When the pressurization system was turned on the heating coils in the air handling unit continued to heat resulting in an average stairwell temperature of $30^{\circ} \mathrm{C}\left(86^{\circ} \mathrm{F}\right)$. The tests with all the doors closed and with two doors open were conducted under these conditions. The test with three doors open was taken with the heating coil turned off and an average stairwell temperature of $22^{\circ} \mathrm{C}\left(72^{\circ} \mathrm{F}\right)$. Velocities were measured in the same manner as was done with Bullding No. 1 . With two doors open the differential pressure across the second floor door fluctuated from an overpressure of 3.7 pascals $\left(0.015\right.$ inches $\left.\mathrm{H}_{2} 0\right)$ to a negative stairwell pressure of 3.7 pascals. The negative pressure indicates a reverse flow of air through doorway cracks into the stairwell. The velocities do not follow the pattern observed in the earlier tests. This may have been caused by the varying wind conditions. When two doors were open the pressures dropped considerably. However, when three doors were open the pressure at the top was the same as with all doors closed. This might have been caused by the difference in stairwell temperatures. The heated pressurization air resulted in lower pressure differentials than the unheated air. This difference was probably due to the differences in air densities between the stairwell and building. The performance of a stairwell pressurization system therefore appears to be degraded when the pressurization air is heated.

\subsubsection{Tracer Test}

The simulated burn room was located on the second floor of the east wing across the corridor from Stairwell No. 3 as shown on figure 12 . 
The fire doors to the elevator lobby were closed on all floors and the fifth floor door to Stairwell No. 3 was opened. Figure 13 shows the $\mathrm{SF}_{6}$ concentrations during this test. A member of the Fire Marshal's office went into the second floor guest room, which is across the hall and one door toward the elevator lobby from the burn room, and collected samples at the start of the test and every five minutes following. The concentration in the guest room increased rapidly and reached $100 \%$ of burn room concentration at 15 minutes. This was due to the corridor pressure caused by the air leakage from the pressurized stairwell. The elevator lobby reached $100 \%$ of burn room concentration after 30 minutes.

Until 40 minutes all the stairwell concentrations were below one percent. At approximately 27 minutes the ground level door to the stairwell was held open. This had no effect upon the successful operation of the pressurization system. The $\mathrm{SF}_{6}$ test was performed with the same wind and temperature conditions as the pressure test with three doors open. However, if the wind and temperature conditions had been similar to those of the test with two doors open the system might have failed. The failure of the roof mounted exhaust fan to operate apparently had no adverse effect upon overall system performance. In fact, if the fan were replaced with a barometric damper the system probably would have worked as we11.

\section{DISCUSSION}

6.1 The $\mathrm{SF}_{6}$ and smoke candle tests on Building No. 1 illustrated the possible problem of smoke feedback into a pressurized stairwell. This situation can exist during special weather conditions and therefore the test is not readily repeatable. The test does emphasize the importance of specifying adequate separation of vents and exhausts from supply fan inlets. Even with the smoke feedback, the pressurization system was partially successful. During the first 15 minutes of the $\mathrm{SF}_{6}$ test the stairwell concentrations were all less than $2 \%$ of the burn room. In a real fire situation this would provide important evacuation time during the initial stages of the fire. Of course, if the separation distance between the elevator vent and the fan intake were less, the contamination would have been much more severe.

6.2 The slight corridor overpressure, from the stairwell leakage, forced smoke and $\mathrm{SF}_{6}$ into the rooms adjacent to the fire corridor. Generally a slight corridor overpressure is considered advantageous because it helps to keep the corridor free of smoke from fires originating in adjacent spaces. If a room fire were to develop sufficient pressure due to thermal expansion and buoyancy it would overcome the corridor overpressure. This would result in smoke flowing from the fire room into the corridor. This is the situation which the $\mathrm{SF}_{6}$ tests simulate and it is a more severe case than many real fire situations. If the stairwell door is open, a larger corridor overpressure results, as was the case in the smoke candle test. In cases where the fire in the room has not reached flashover, this overpressure in the corridor could prevent smoke from infiltrating the corridor. 
6.3 The fact that the stairwell exhaust fan in Building No. 2 never operated raises the question of whether stairwel1 exhaust fans are necessary. Ideally the exhaust fan eliminates smoke which might infiltrate a stairwell and prevents excessive stairwell pressures. However, in the case of the bottom injection system already discussed, the exhaust fan pulled air from the upper floors into the stairwell when three lower level doors were open. At present there is insufficient information to properly evaluate the value of exhaust fans and further study is needed.

6.4 The heated pressurization air in Building No. 2 resulted in lower pressure differentials than the unheated air. This difference was probably due to the differences in air densities and indicates that the performance of a stairwell pressurization system is degraded when the pressurization air is at a higher temperature than the building.

6.5 Future efforts in this program will include continued testing of different pressurization systems. The tests of Building No. 2 will be repeated and expanded when building construction is complete and the entire heating and cooling system is balanced. Future tests will investigate the effects of supply air flow rates, weather conditions, control methods and of different locations of supply air inlets. The function of exhaust air fans will also be examined. 


\section{REFERENCES}

[1] Ecnjamin, I. A., Fung, F., and Roth, L., Control of smoke movement in buildings: a review, Nat. Bur. Stand. (U.S.), NBSIR 77-1209 (July 1977).

[2] Cresci, R. J., Smoke and Fire Controls in High-Rise Office Buildings - Part II: Analysis of Stair Pressurization Systems, ASHRAE Symposium on Experience and Applications on Smoke and Fire Control, Louisville, Kentucky, June 1973, p. 16-23.

[3] Minni, R., Smoke Infiltration into the Fire-Escape Routes of Tall Buildings, CIB Symposium on the Control of Smoke Movement in Building Fires, Vol. I, Watford United Kingdom, Nov. 1975, p. 245-266.

[4] denOuden, L., The Effect of Opening and Closing of Doors on the Pressure Levels in a Building in which the Stair-well is Pressurized, CIB Symposium on the Control of Smoke Movement in Building Fires, Vol. II, Watford United Kingdom, Nov. 1975, p. 42-49.

[5] Hobson, P. J. and Stewart, L. J., Pressurization of Escape Routes in Buildings, Heating and Ventilating Research Association, Bracknell Berkshire, England, Jan. 1973.

[6] Tamura, G. T. and Shaw, C. Y., Air Leakage Data for the Design of Elevator and Stair Shaft Pressurization Systems, ASHRAE Technical Paper No. 2413.

[7] Standard Building Code, Southern Building Code Congress International, Inc., Birmingham, AL (1976 Edition with 1979 Revisions).

[8] Basic Building Code, Building Officials and Code Administrator's International, Inc., Chicago, IL (1978 Edition).

[9] Uniform Building Code, International Conference of Building Officials, Whittier, CA(1976 Edition with 1979 Revisions).

[10] DeCicco, P. R., Cresci, R. J., Correale, W. H., Report of Fire Tests, Analysis, and Evaluation of Stair Pressurization and Exhaust in High-Rise Office Buildings, performed for the City of New York by the Polytechnic Institute of Brooklyn, Baywood Publishing Company, Sept. 1972.

[11] Fung, F. C. W., Evaluation of a pressurized stairwell smoke control system for a 12 story apartment building, Nat. Bur. Stand. (U.S.), NBSIR 73-277 (June 1973).

[12] Hedsten, G. C., Building and Stair Pressurization System, ASHRAE Journal, July 1978, p. 32-35. 
[13] Dias, C., Stairwe11 Pressurization in a High-Rise Building, ASHRAE Journal, July 1978, p. 24-26.

[14] Hunt, C. M. and Treado, S. J., A prototype semi-automatic system for measuring air infiltration in buildings using sulfur hexafluoride as a tracer, Nat. Bur. Stand. (U.S.), Tech. Note 898 (March 1976) p. 4. 


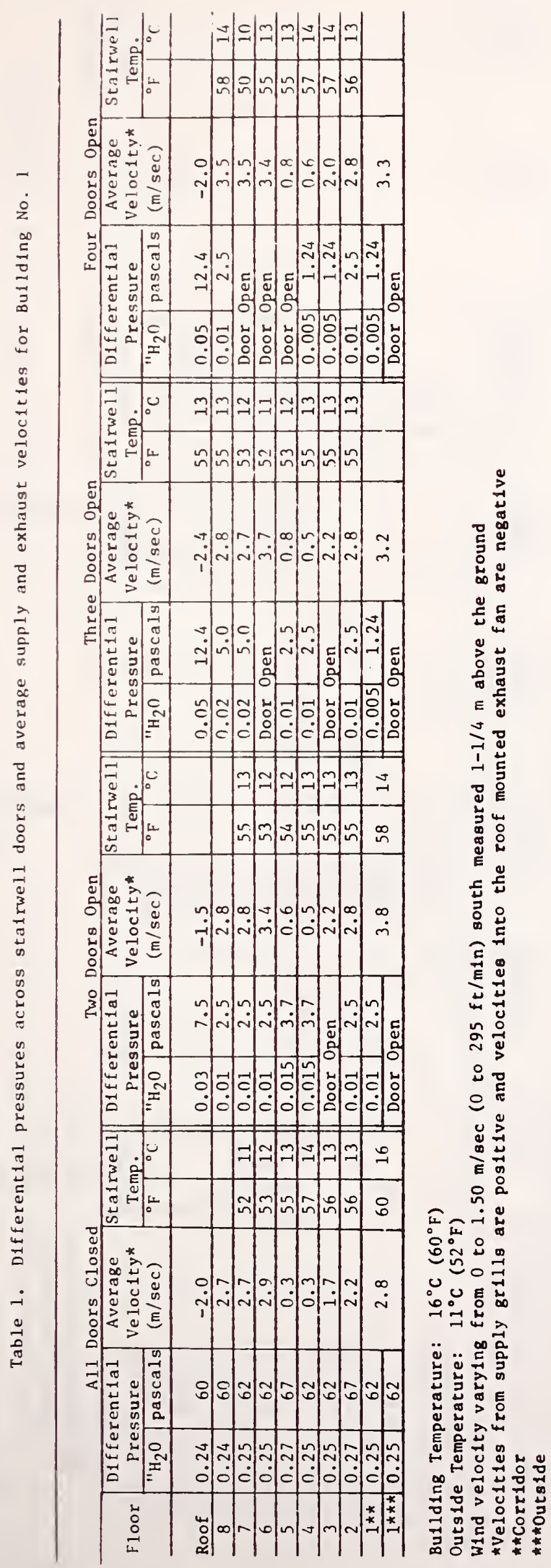




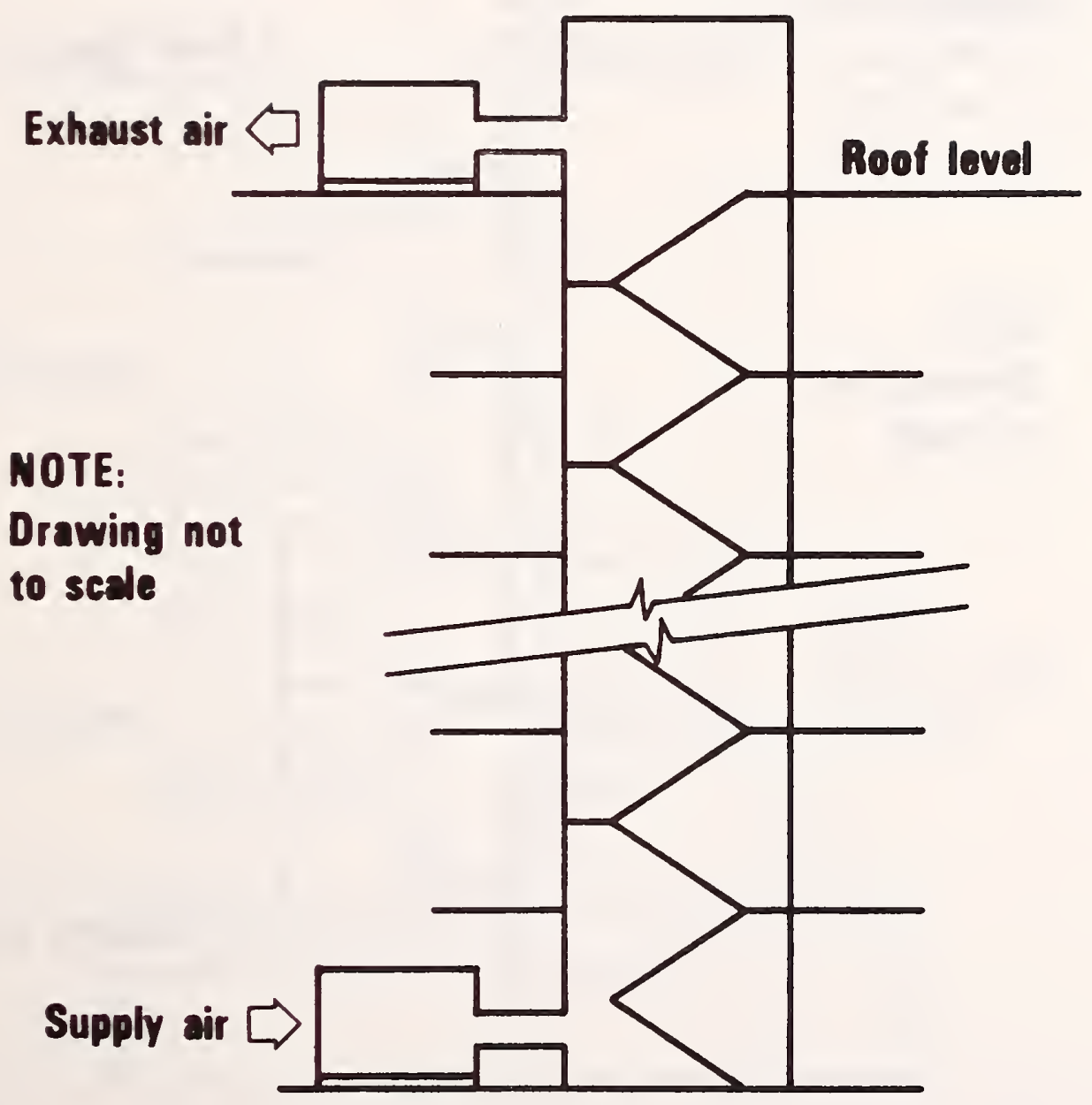

Figure 1. Diagram of bottom injection stairwell pressurization system 


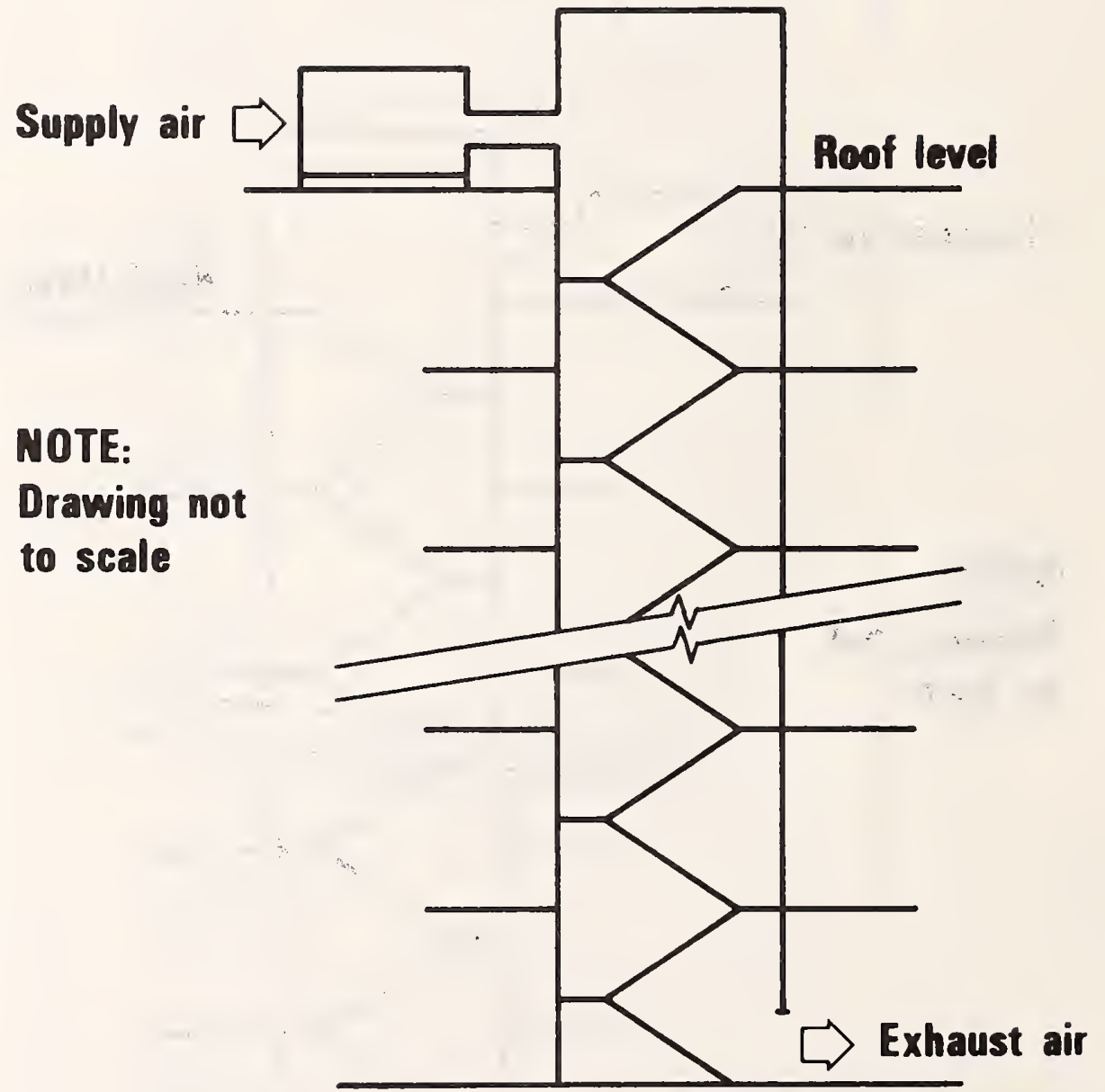

Figure 2. Diagram of top injection stairwell pressurization system 


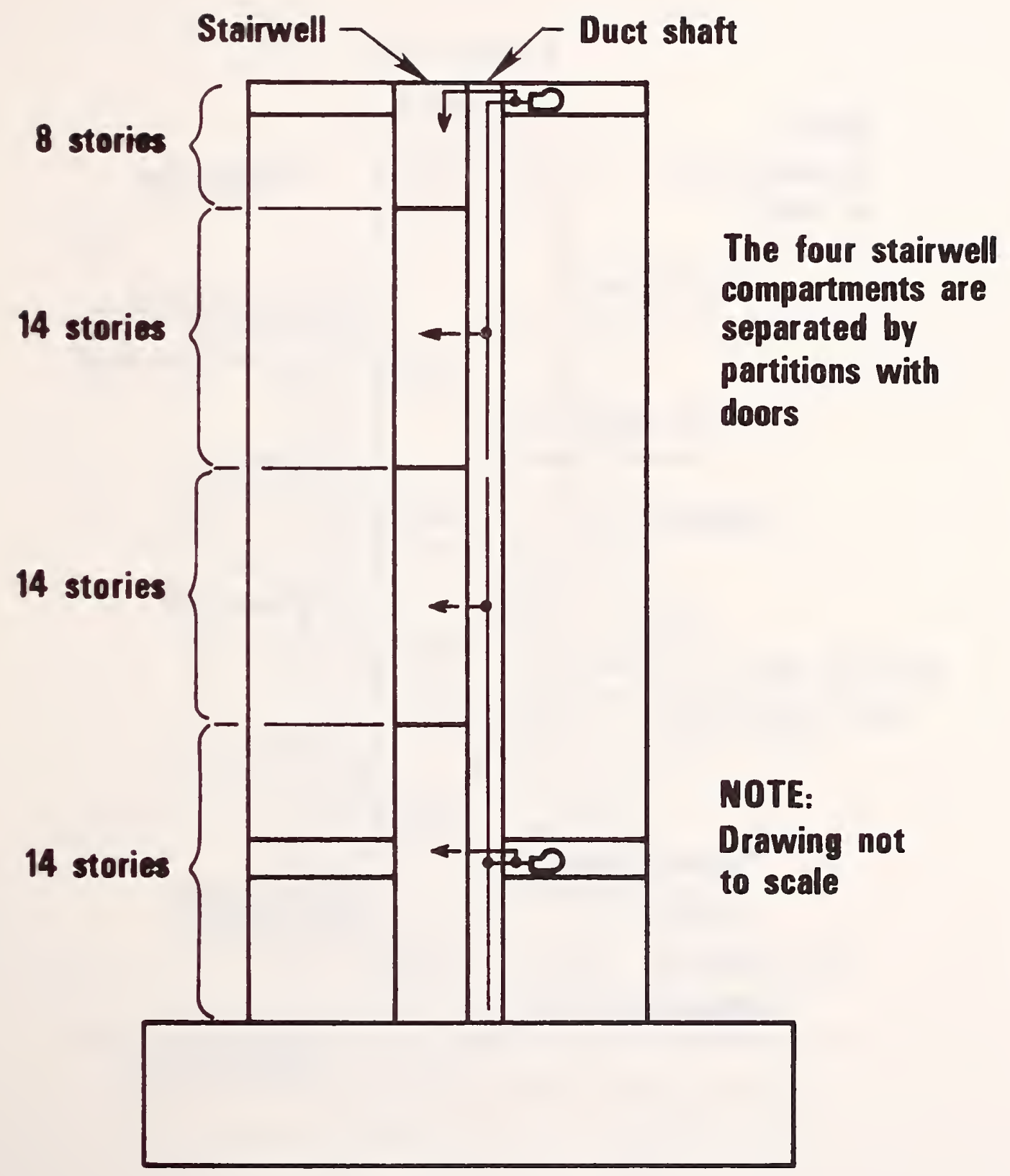

Figure 3. Compartmentalization of stairwell in the IDS Center in Minneapolis 


\section{Exhaust fan}

\section{NOTE: \\ Drawing not to scale}
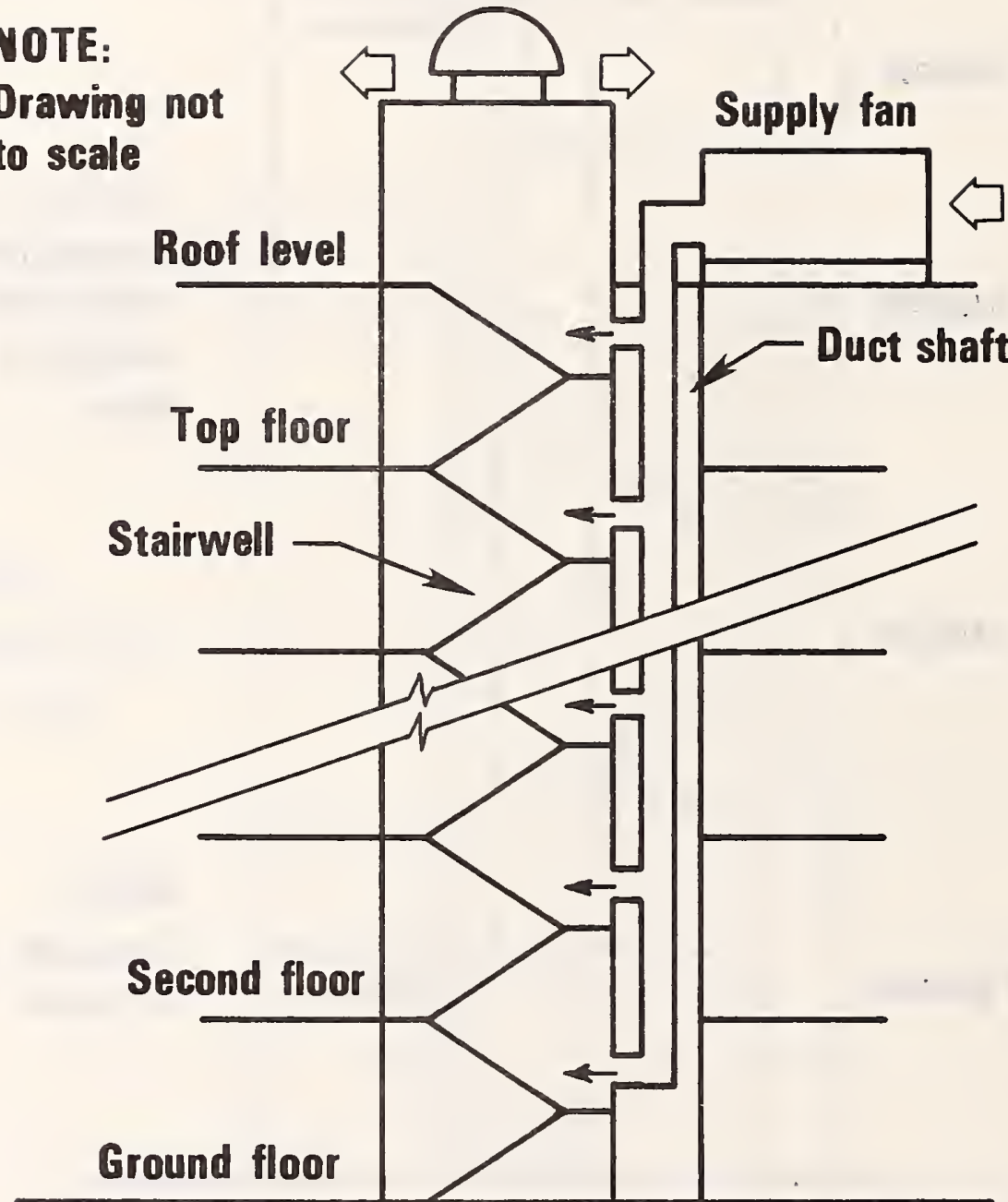

Figure 4. Multiple injection system with an exhaust fan and a roof mounted supply fan 


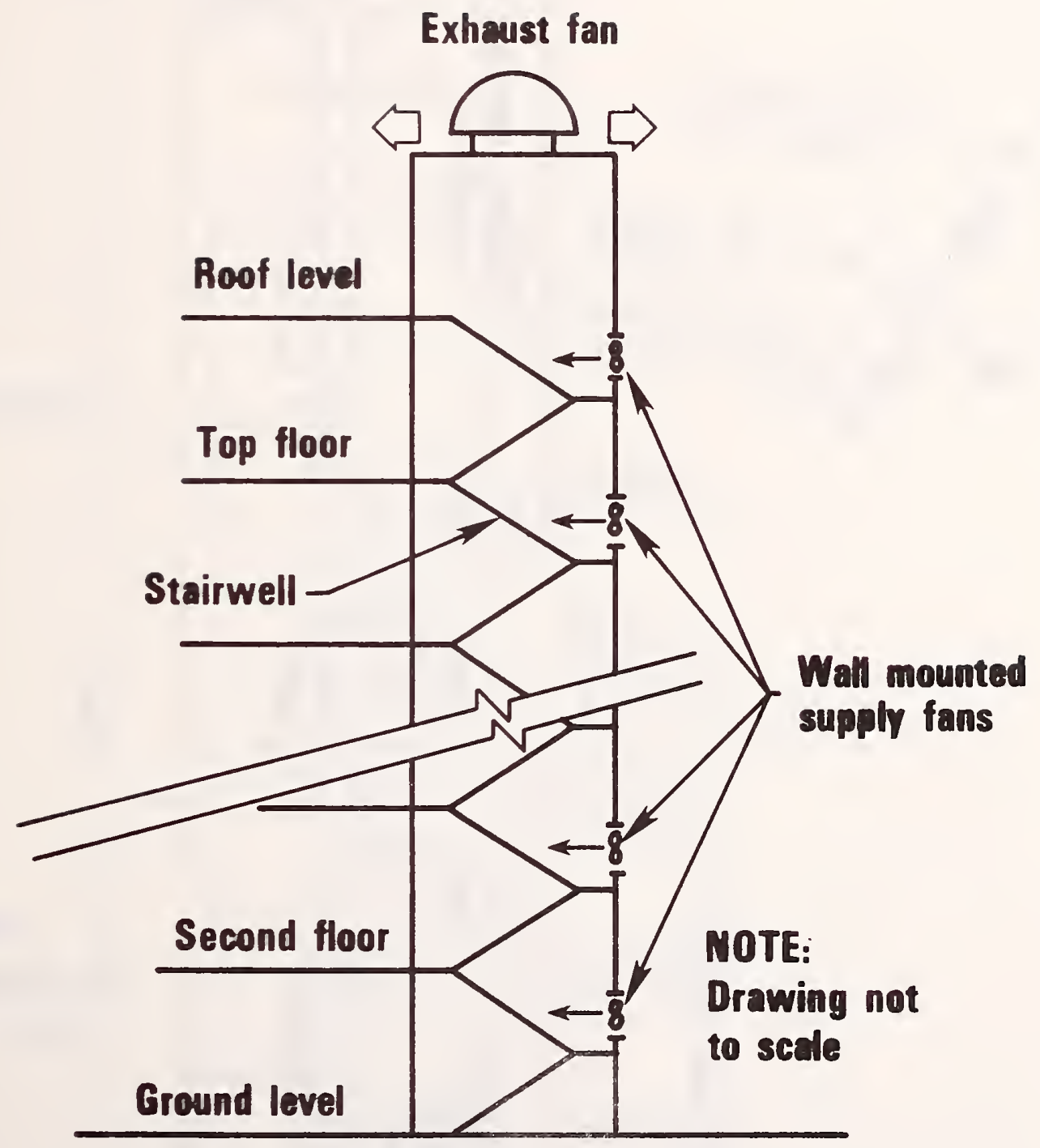

Figure 5. Multiple injection system with an exhaust fan and several wall mounted supply fans 

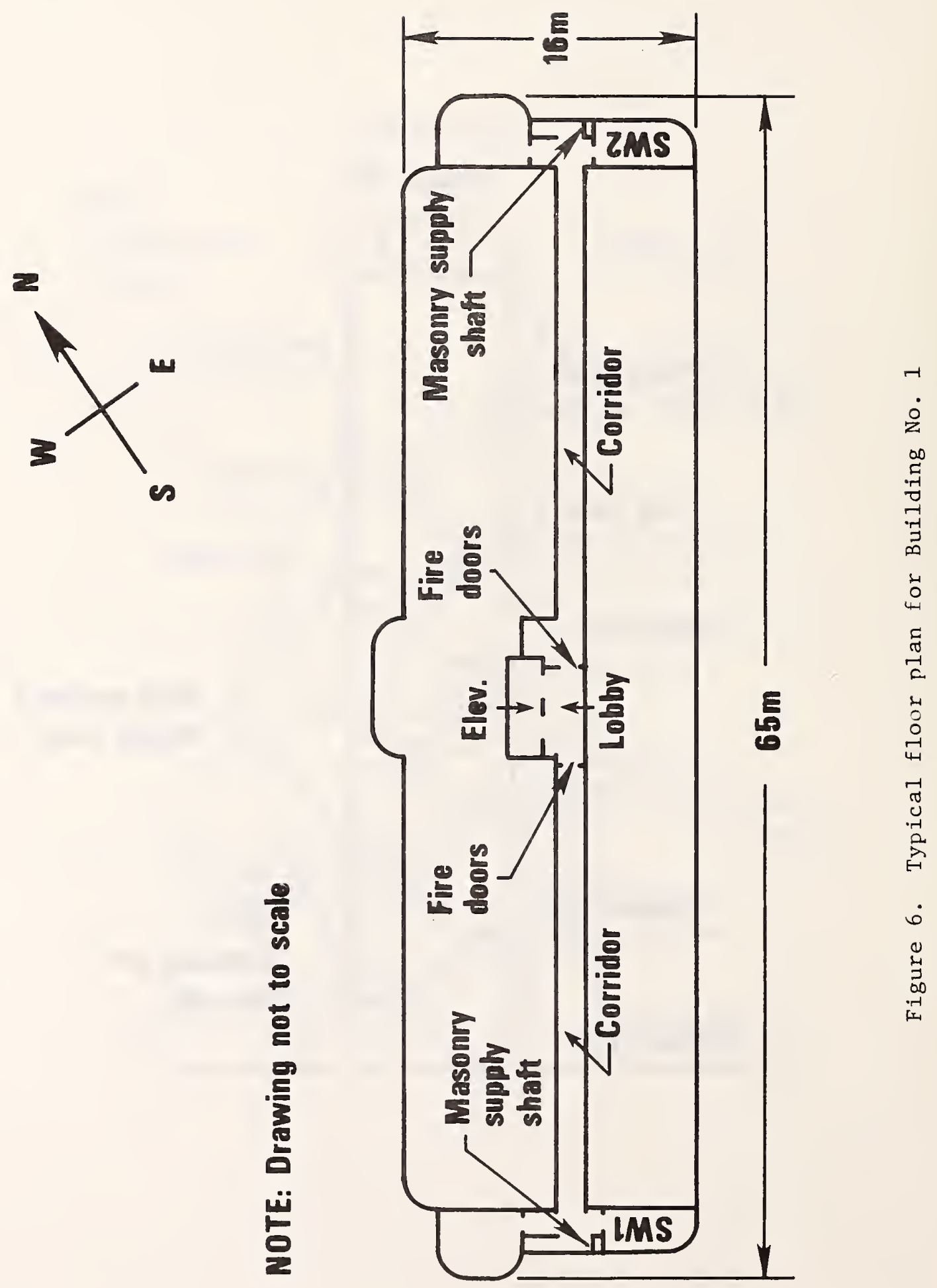


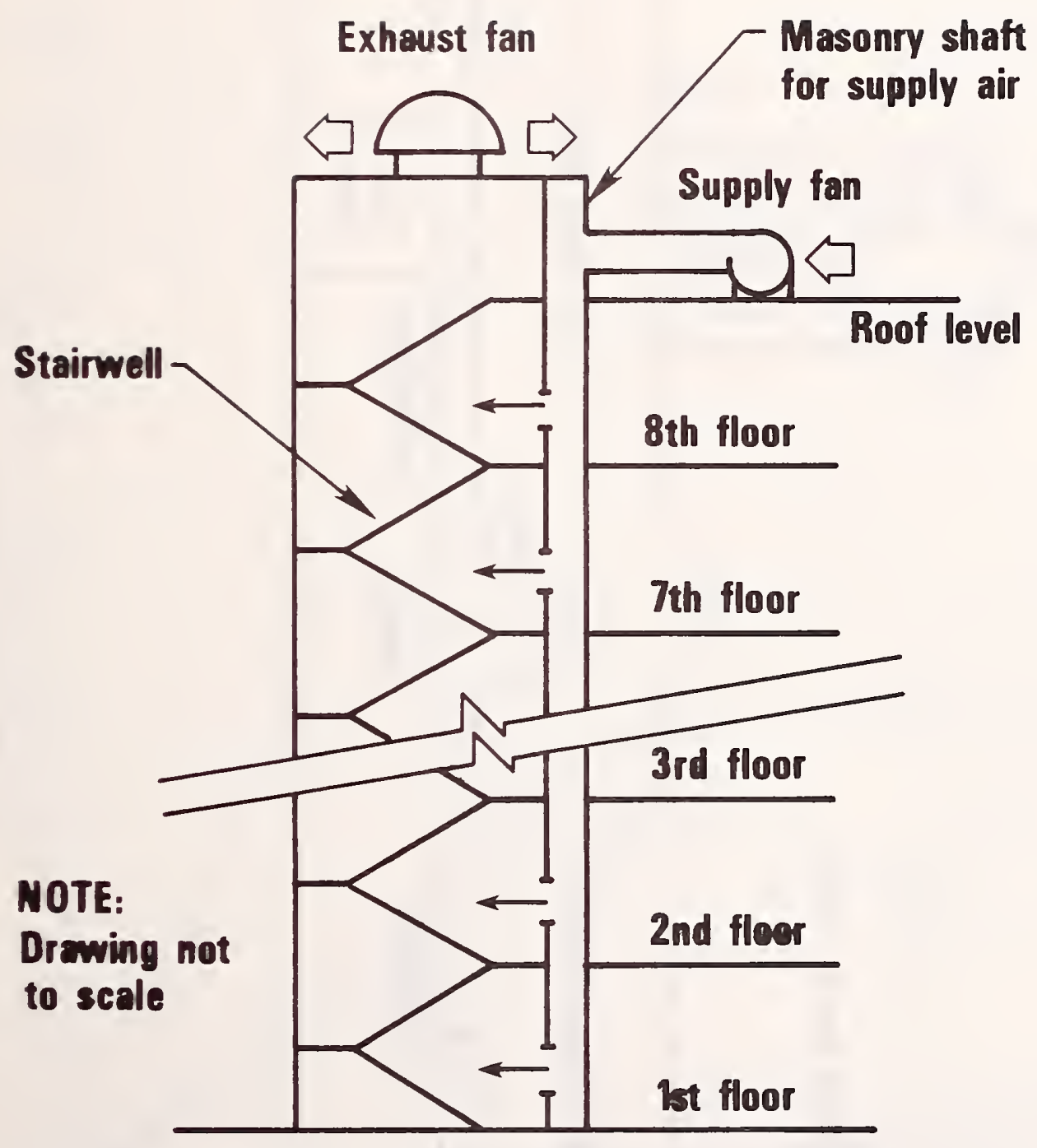

Figure 7. Diagram of stairwell pressurization system for Building No. 1 

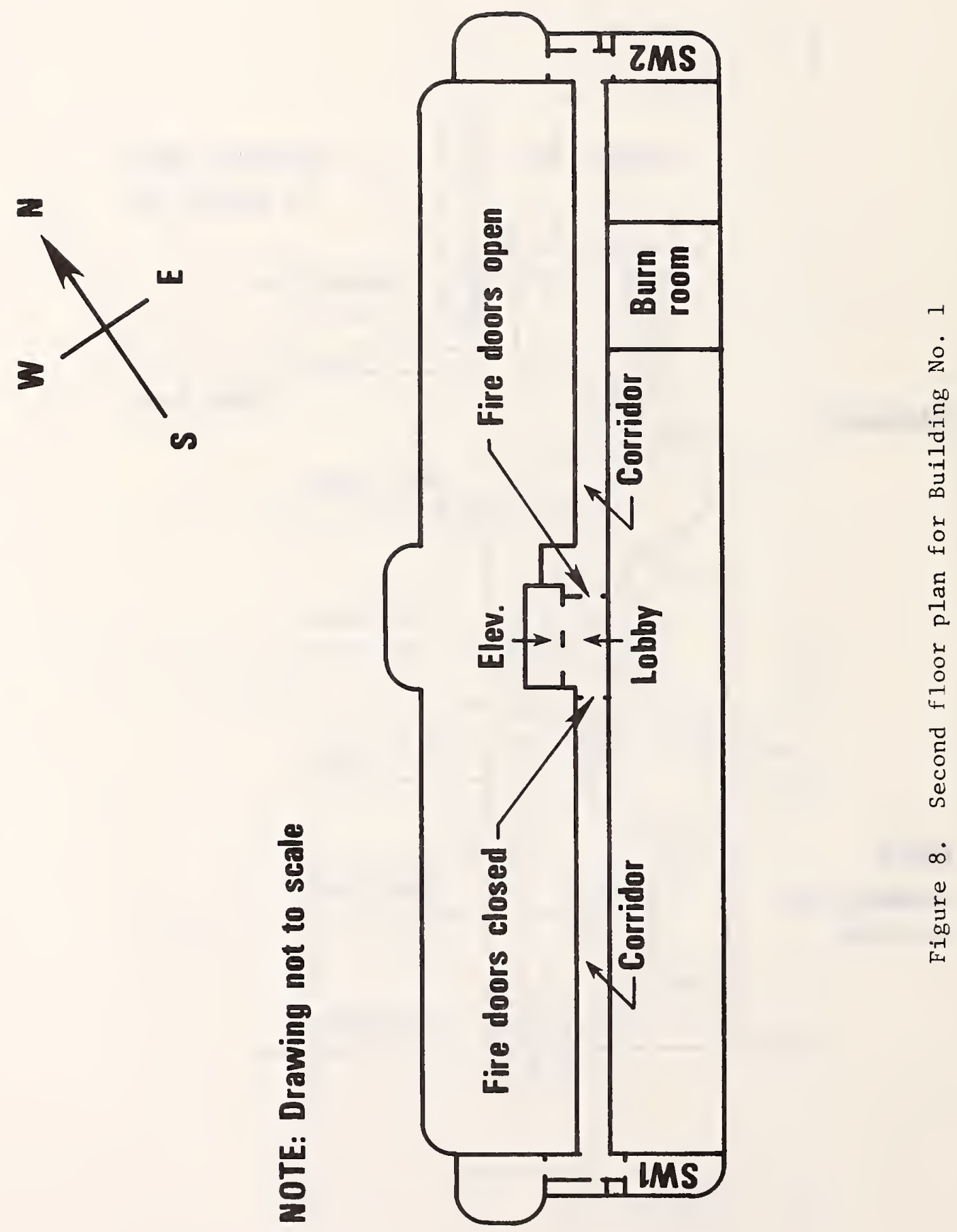


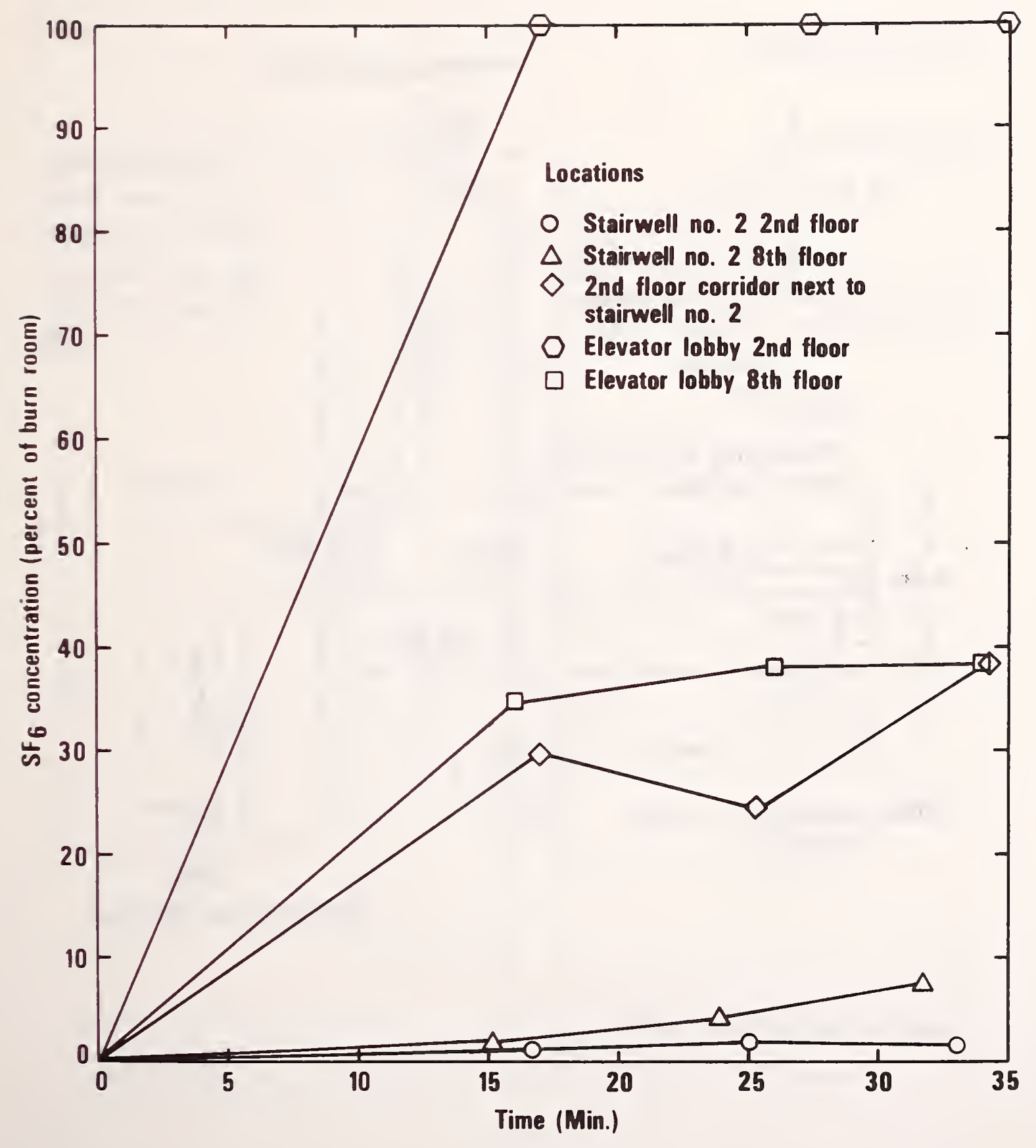

Figure 9. $\mathrm{SF}_{6}$ concentrations for Building No. 1 
East wing (to 17th floor)

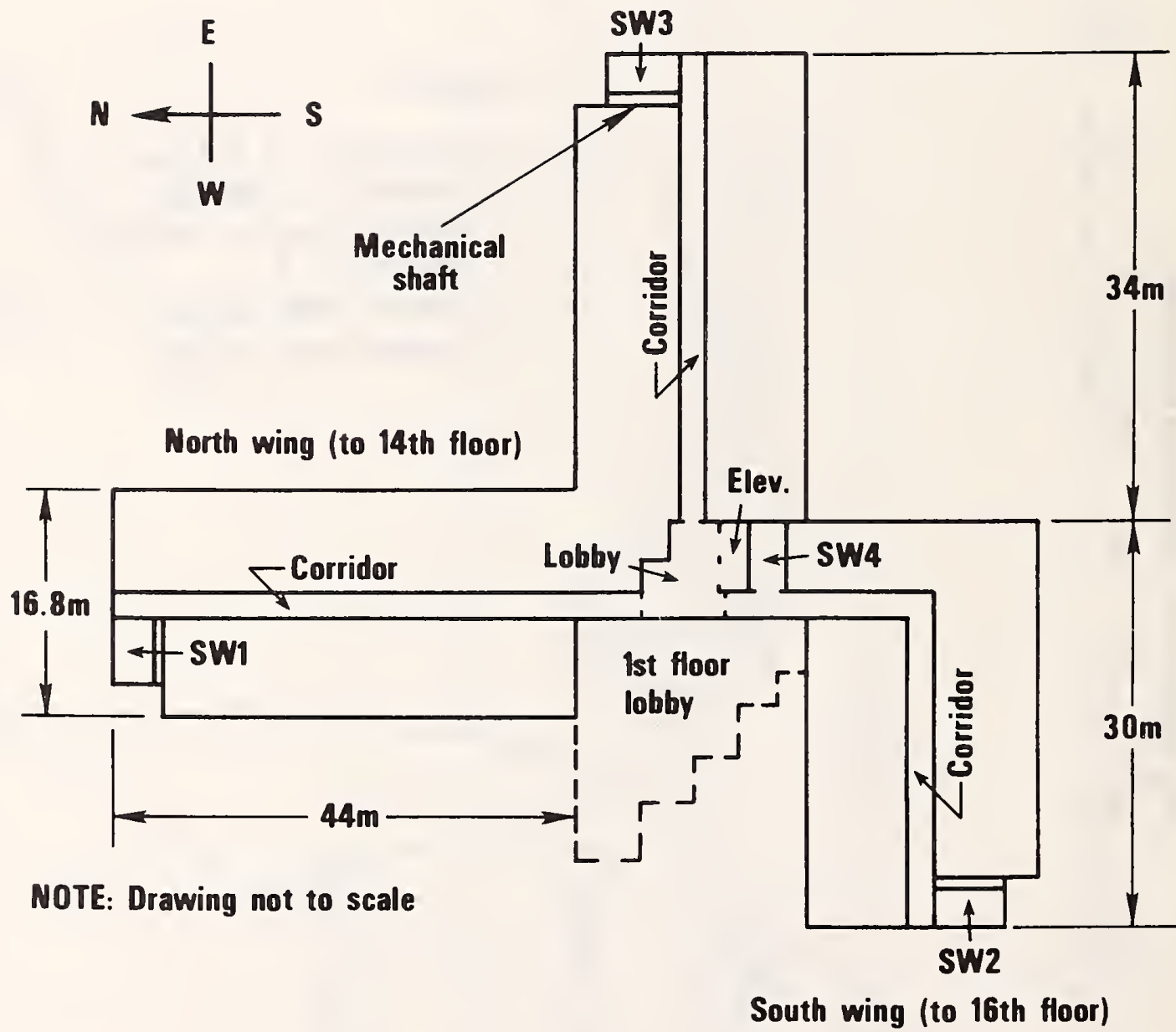

Figure 10. Typical floor plan for Building No. 2 


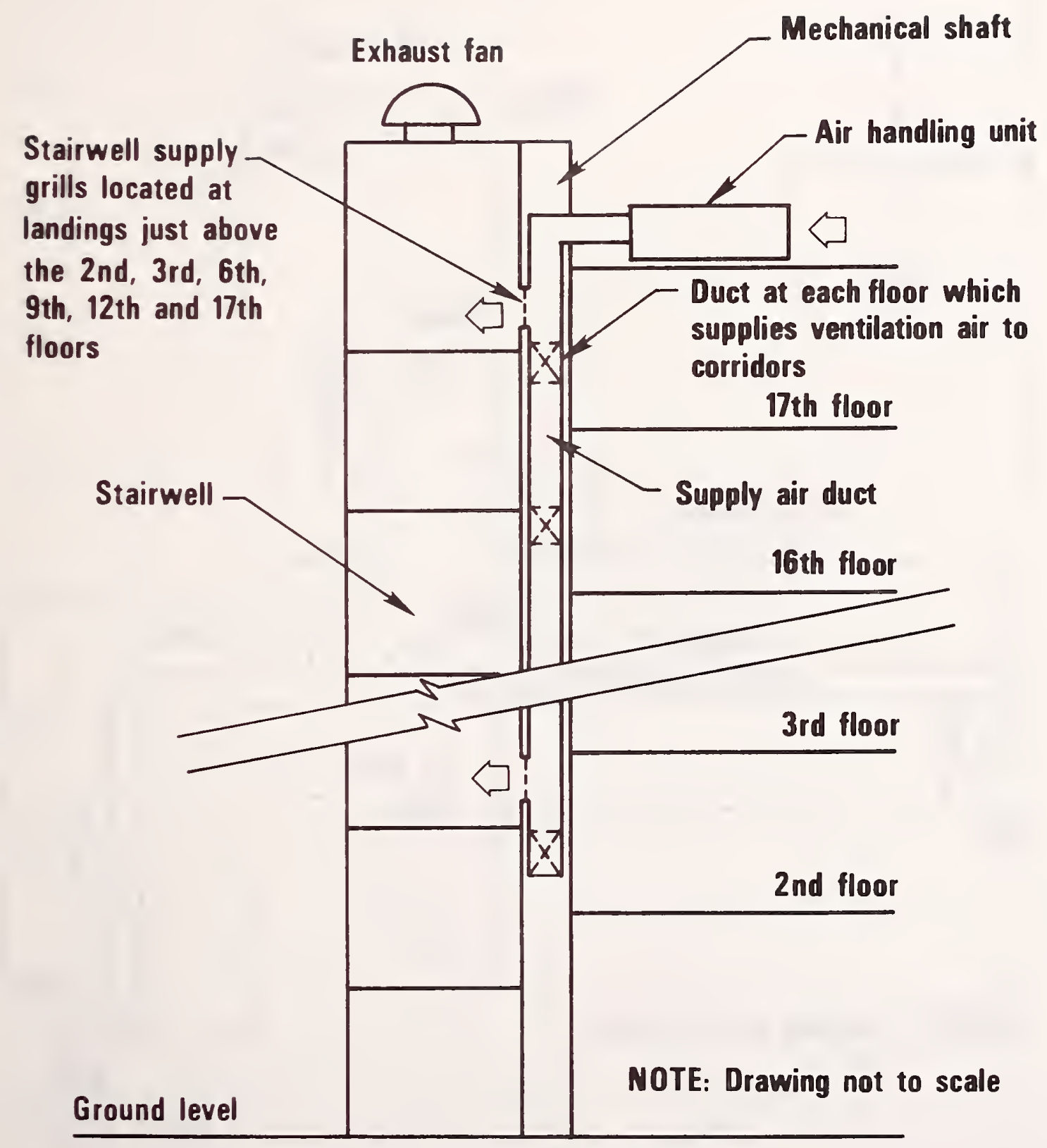

Figure 11. Diagram of stairwell pressurization system for Building No. 2 


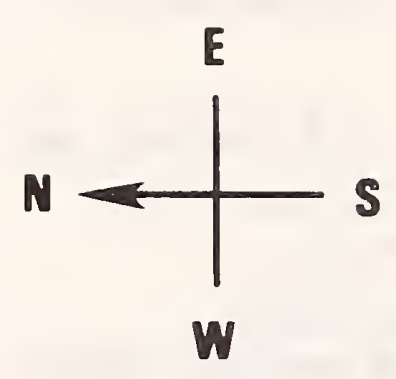

\section{East wing}

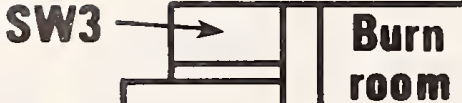

North wing

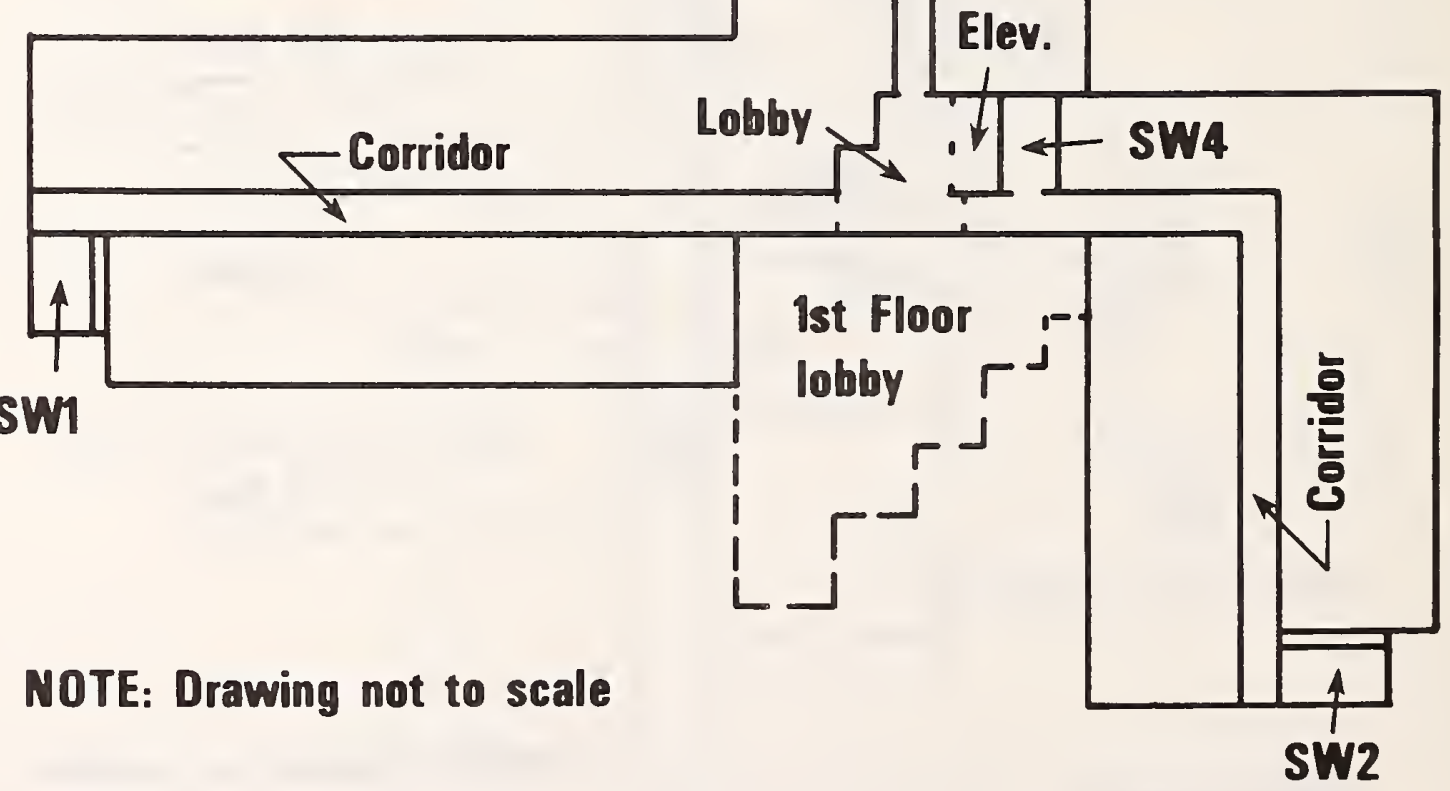

South wing

Figure 12. Second floor plan for Building No. 2 


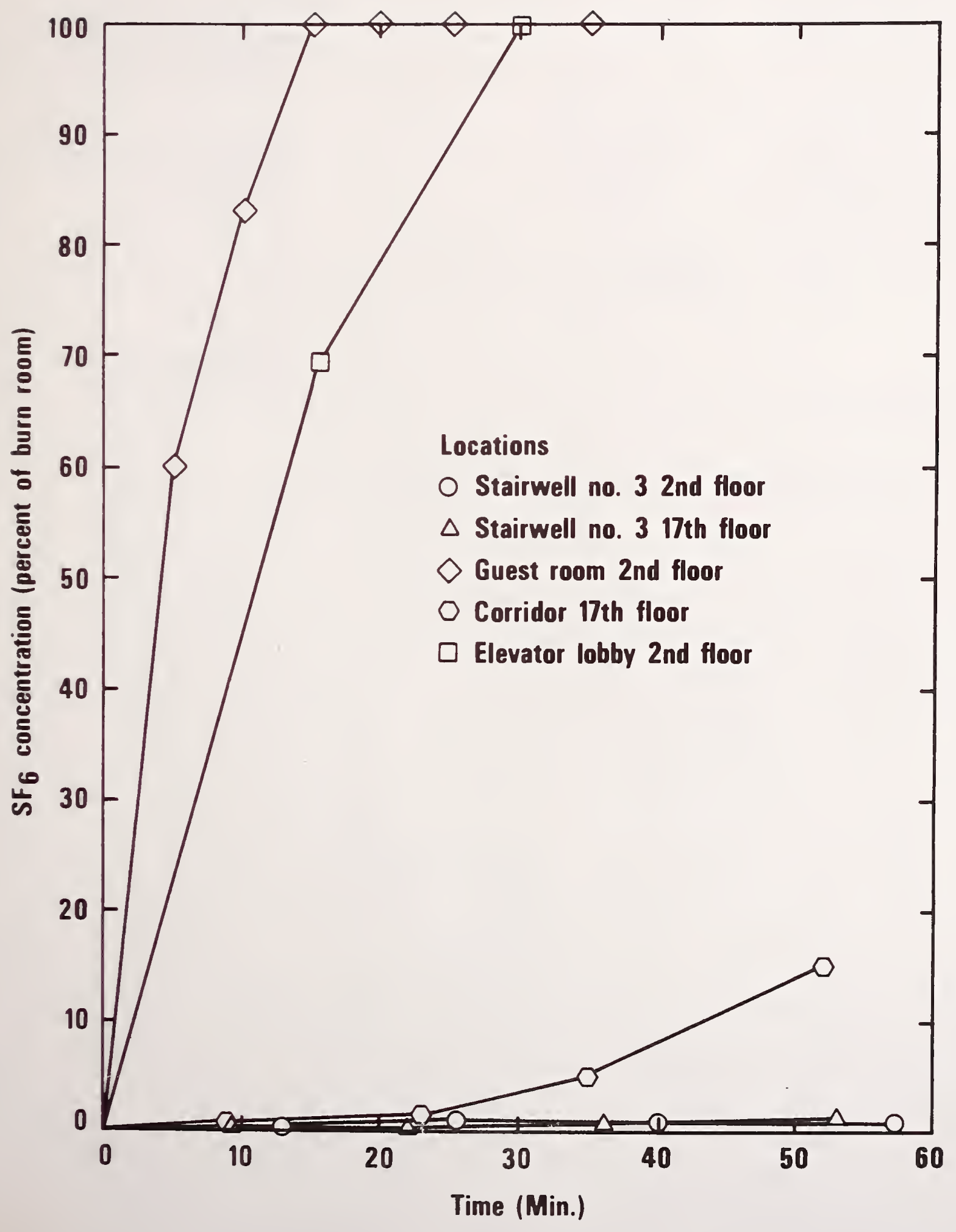

Figure 13. $\mathrm{SF}_{6}$ concentrations for Building No. 2 
NBS-114A (REV. 0.78 )

\begin{tabular}{|c|c|c|c|}
\hline $\begin{array}{l}\text { U.S. DEPT. OF COMM. } \\
\text { BIBLIOGRAPHIC DATA } \\
\text { SHEET }\end{array}$ & $\begin{array}{l}\text { 1. PUBLICATION OR REPORT NO. } \\
\text { NBSIR } 79-1747\end{array}$ & 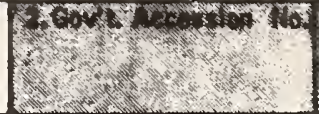 & 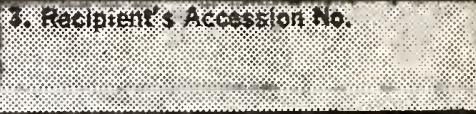 \\
\hline \multicolumn{3}{|l|}{ 4. TITLE AND SUBTITLE } & $\begin{array}{l}\text { 5. Publication Date } \\
\text { June } 1979\end{array}$ \\
\hline \multicolumn{3}{|c|}{ STAIRWELL PRESSURIZATION SYSTEMS } & CFor orming orcanization code \\
\hline \multicolumn{3}{|c|}{$\begin{array}{l}\text { 7. AUTHOR(S) } \\
\text { Irwin A. Benjamin \& John H. Klote }\end{array}$} & 8. Performing Organ. Report No. \\
\hline \multirow{2}{*}{\multicolumn{3}{|c|}{$\begin{array}{l}\text { NATIONAL BUREAU OF STANDARDS } \\
\text { DEPARTMENT OF COMMERCE } \\
\text { WASHINGTON, DC } 20234\end{array}$}} & 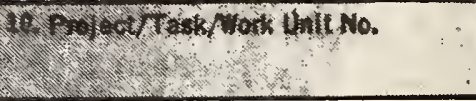 \\
\hline & & & 11. Contract/Grant No. \\
\hline \multirow{2}{*}{\multicolumn{3}{|c|}{$\begin{array}{l}\text { 12. SPONSORING ORGANIZATION NAME AND COMPLETE ADDRESS (Streot, City, State, zIP) } \\
\text { (Same as No. 9) }\end{array}$}} & $\begin{array}{l}\text { 13. Type of Report \& Period Covered } \\
\text { Final }\end{array}$ \\
\hline & & & ST so foroming Agency Codo \\
\hline
\end{tabular}

15. SUPPLEMENTARY NOTES

1 Document describes a computer program; SF-185, FIPS Software Summary, is attached.

16. ABSTRACT (A 200-word or less tactual summary of most significant information. If document includes a significant bibliography or literature survey, mention it here.)

The use of stairwell pressurization systems has grown in the U.S. over the past few years. However, there are no accepted design procedures for the systems. The paper discusses several of the designs now being used in the U.S., with some of the assumptions used for design of the systems. In particular, single and multiple injection systems are discussed. A report is made on field tests on two systems. The testing is part of a continuous program to evaluate alternate systems, in an attempt to establish design recommendations for the future.

17. KEY WORDS (six to iwelve entries; alphabotical ordes; capitalize only the first letter of the first koy word unleas a proper namo; separated by semicolons)

Bottom injection: multiple injection; smoke candle test; smoke control: stairwell pressurization: top injection; tracer gas test.

18. AVAILABILITY

$$
[\mathrm{x}] \text { Unlimited }
$$

"] For Official Distribution. Do Not Release to NTIS

I Order From Sup. of Doc., U.S. Government Printing Office, Wasinington, DC 20402, SD Stock No. SNÓ03-003-

X Order From National Technical Information Service (NTIS), Springfield, VA. 22161

\begin{tabular}{|l|l|}
\hline $\begin{array}{l}\text { 19. SECURITY CLASS } \\
\text { (THIS REPORT) }\end{array}$ & $\begin{array}{l}\text { 21. NO. OF } \\
\text { PRINTED PAGES } \\
\text { UNCLASSIFIED }\end{array}$ \\
\hline $\begin{array}{l}\text { 20. SECURITY CLASS } \\
\text { (THIS PAGE) }\end{array}$ & 22. PrICe \\
UNCLASSIFIED & \\
\hline
\end{tabular}



